\title{
Assesing the Financial Performance: in Perspective Environmental Performance, CSR, GCG, and Leverage
}

\author{
Agda Laily Ahadiya \\ Department of Management, STIE Perbanas Surabaya, Surabaya \\ e-mail: agdalailyahadiya@gmail.com
}

\begin{abstract}
The company has a goal to generate maximum profit. However, the dry season in 2019 used by them to carried out "land clearing" of the forest to make profits in a bad way. This is conseptual research and qualitative research that aims to analyze the influence between variables. This research analyzes the effect of Environmental Performance, Corporate Social Responsibility (CSR), Good Corporate Governance (GCG) as a non-financial aspect and Leverage as financial aspect on Financial Performance. This research is designed by qualitative research with theoretical reviews as the main method. The authors conducted a systematic review of the articles that were identified from international and national business journals published between 2014 and 2019. There is three basic theory about agency theory, stakeholder theory, and trade-off theory as the foundation for reviewing some previous research. By the classifying the result found some propositions: 1) The good of environmental performance affect positive financial performance, 2) The higher disclosure of Corporate Social Responsibility affects the financial performance to be good, 3) The good implementation of Good Corporate Governance can make the financial performance to be good and, 4) The good ratio of Leverage will affect positively the financial performance.
\end{abstract}

Keywords-Return On Assets, PROPER, Corporate Social Responsibility, Good Coorporate Governance, Leverage.

\section{INTRODUCTION}

$\mathrm{T}$ HE establishment of a company has the aim to generate the maximum possible profit by managing resources effectively and efficiently. At present, competition in the business world has increased and is tight so that many companies are competing to improve the company's financial performance by maximizing profit achievement. The company's financial performance is an analysis to see how a company has implemented financial rules properly and correctly. Every year the company will continue to strive to improve its financial performance by first analyzing available financial information so that it looks relevant to attract the attention of stakeholders, especially investors.

However, the event of the dry season in 2019 was used by some companies in making profits in an improper way. They do the practice of "land cleaning" in an easy and inexpensive way to get profits for their company. As a result, many haze disasters occur in various regions of Indonesia, especially in September 2019. The Ministry of Environment and Forestry (KLHK) conducted a press release on 28 September 2019 related to the percentage of forest and land fires (forest and land fires) that have decreased. Based on data obtained from the Information Management and Documentation Officer
Table 1.

Number of Hotspot Distributions September 25, 2019

\begin{tabular}{cc}
\hline \hline Location & Number of Hotspot \\
\hline Riau & 68 points \\
Jambi & 15 points \\
South Sumatera & 13 points \\
West Kalimantan & 9 points \\
Central Kalimantan & 268 points \\
South Borneo & 39 points \\
East Kalimantan & 60 points \\
\hline \hline
\end{tabular}

Table 2.

Number of Hotspot Distributions September 28, 2019

\begin{tabular}{cc}
\hline Location & Number of Hotspot \\
\hline Riau & 28 points \\
Jambi & 17 points \\
South Sumatera & 3 points \\
West Kalimantan & - \\
Central Kalimantan & 4 points \\
South Borneo & 1 point \\
East Kalimantan & 27 points \\
\hline \hline
\end{tabular}

(PPID) there were 554 points recorded on 25 September 2019.

The Ministry of Environment and Forestry (KLHK) has sealed 42 companies that are suspected to be the cause of the forest and land burning. This problem has become the spotlight because of environmental pollution in Indonesia in the form of smoke disasters quite disturbing the surrounding community. As a company that is responsible and has social care, the company must pay attention to the environment and the needs of the surrounding community. In traditional accounting theory, a company is considered to provide many benefits to the community by maximizing its profits to be able to make a maximum contribution also to the community [1]. However, now the community is increasingly aware of the impact of environmental problems caused by the company in carrying out its operations, especially after a recent forest and land fire event.

Ni Luh Putu Widhiastuti, ID. G. Dharma Saputra and IG. A. N. Budiasih (2017) [2] conducted research related to a company's PROPER level on the company's financial performance. The result is a link between these two things, the higher the PROPER level of a company, the financial performance of the company also increases. Ni Luh Putu, et al's research is supported by the results of a study conducted by Rima Dewi (2019) [3] relating to environmental performance and corporate financial performance. The results of this study indicate that environmental performance will 
The $1^{\text {st }}$ International Conference on Business and Engineering Management (IConBEM)

February $1^{\text {st }} 2020$, Institut Teknologi Sepuluh Nopember, Surabaya, Indonesia

affect the profits generated by the company. Effendi argues, that currently there is a trend towards increasing public demands for transparency and accountability of the company by implementing Corporate Social Responsibility (CSR) to increase awareness of goods (products) that are environmentally friendly [4]. However, sometimes the company forgets the social responsibility because the company feels the stakeholders do not contribute well enough to the survival of the company, especially in terms of social responsibility. Andreas defines the meaning of CSR is "A company must be responsible for every action that impacts society, the community, and their environment" [5]. Thus, the business world has begun to be demanded to align profit achievement with social performance and environmental performance.

Joko (2016) [6] conducted a study related to CSR. The results of his research indicate that CSR has an effect but is not significant on ROA. The results of this study are supported by further research conducted by Rima Dewi (2019) [3] which shows the results of CSR affect the increase in company profits and also research conducted by ElifAkben (2019) [7] which shows that increased CSR in the company will increase the company's ROA.

In addition to implementing CSR by companies, the Asian Corporate Governance Association (ACGA) has also conducted a survey related to the implementation of Good Corporate Governance (GCG) in Indonesia, which is still not satisfactory. GCG is definitively a system that regulates and controls companies to create added value for all stakeholders [8]. The implementation of transparent, professional GCG principles and clean management work patterns will attract domestic or foreign stakeholders.

In an effort to implement GCG, the company elects a board of commissioners (board of commissioners) to carry out responsibilities related to the implementation of GCG. This Board of Commissioners functions as a supervisor in the company and helps the board of directors to manage the company. A full commitment is needed between the two so that the implementation of GCG can run well. The company must also make improvements to the commissioners, where the improvements are considered to carry out empowerment which will later become a driver of GCG.

Based on the data, Arief (2016) [4] explained, that at the beginning of 2014 of a total of 489 companies listed on the IDX, there were still around $12 \%$ of publicly listed companies (Tbk) that set the term of independent commissioners for only one year, while the remaining approximately $88 \%$ the position of independent commissioner for three to five years [4]. Someone who has served as an independent commissioner more than twice is considered too long so that it is feared that it will reduce the level of independence in the company.

Syahrul (2018) conducted a study, which examined the effect of GCG represented by the board of commissioners, independent board of commissioners, and audit committee on the company's financial performance [9]. The results showed that the results of the board of commissioners affect ROA, while the independent board of commissioners and the audit committee did not affect the company's financial performance. In contrast to research conducted by Riri Mayliza, et al (2019) [10], the results show that the audit committee influences ROA as the company's financial performance.

This research is important so that companies can improve financial performance with good governance without ignoring social responsibility and that must be done for the community around the company. So the company gets a positive impact and the community also gets the same thing.

Besides, the level of company financial performance is influenced by many factors, including the efficient management of working capital. Working capital management is considered quite important because the company can see the amount of working capital used by the company economically. If the working capital management gets bigger, the profits will be even greater and this will be useful to increase the profitability of the company. However, if on the contrary, the company is not able to produce good profitability to pay its obligations, then the company must find a source of funds from outside parties. Fulfilling the source of funds through this method will affect the level of corporate leverage because leverage is the ratio used to measure how far the company uses debt. If leverage increases, the profitability of companies decreases. Umer (2018) [11] conducted research related to leverage measured by using Debt to Equity Ratio (DER), solvency, and proprietary ratio. The results showed that DER, solvency and proprietary ratio had a positive effect on ROA. Ilhan (2018) [12] also conducted the same research related to leverage on the company's financial performance. The results of his study indicate that leverage affects ROA. In contrast to research conducted by Makwe S. I. (2019) [13] which shows that leverage measured using the DER ratio does not have a significant effect on ROA.

\section{THEORITICAL REVIEW}

\section{A. Agency Theory.}

An agency relationship will occur when one or more individuals called a principal party hires another individual or organization called an agent to perform some services and delegate authority in making decisions on that agent. This agency theory emphasizes the establishment of efficient contractual arrangements in the relationship between the principal and the agent, where the contract contains a clear picture of all rights and obligations between the principal and agent to minimize agency conflict and minimize agency costs [14].

Three assumptions underlie agency theory according to Darmawati in Andri (2015) [15] namely assumptions about human nature, organizational assumptions, and information assumptions. Assumptions of human nature emphasize that humans have selfishness, have rational limitations (bounded rationality) and do not like risk.

1. Organizational assumptions emphasize the existence of conflicts between members of the organization, efficiency as effectiveness criteria, and the existence of information asymmetry between principals and agents.

2. Information assumption suggests that information is considered as a commodity that can be bought and sold Corporate governance as mechanical effectiveness that aims to minimize agency conflict,

3. Information assumption suggests that information is considered a commodity that can be bought and sold. 
The $1^{\text {st }}$ International Conference on Business and Engineering Management (IConBEM)

February $1^{\text {st }} 2020$, Institut Teknologi Sepuluh Nopember, Surabaya, Indonesia

Table 3.

Interpretation Rating of Proper

\begin{tabular}{cl}
\hline \hline Colour & \multicolumn{1}{c}{ Description } \\
\hline Gold & $\begin{array}{l}\text { The company has consistently demonstrated } \\
\text { environmental excellence in the production and service } \\
\text { processes, as well as carrying out ethical and responsible } \\
\text { business to the community. }\end{array}$ \\
\hline Green & $\begin{array}{l}\text { The company has managed the environment more than } \\
\text { what is required in the regulations (beyond compliance) } \\
\text { through the implementation of the environmental } \\
\text { management system and they have used resources } \\
\text { efficiently and carried out social responsibility well }\end{array}$ \\
\hline Blue & $\begin{array}{l}\text { The company has made the environmental management } \\
\text { efforts required by the provisions of applicable laws }\end{array}$ \\
\hline Red & $\begin{array}{l}\text { The company has made efforts to manage the } \\
\text { environment but not by the requirements as regulated in } \\
\text { the legislation }\end{array}$ \\
\hline Black & $\begin{array}{l}\text { The Company has intentionally committed acts or } \\
\text { committed negligence resulting in pollution or } \\
\text { environmental damage, as well as carrying out } \\
\text { applicable laws and / or not implementing administrative } \\
\text { sanctions }\end{array}$ \\
\hline \hline
\end{tabular}

Riri Mayliza, et al (2019) [10] explain that agency theory is a concept of corporate governance that has a function as a tool in convincing investors that they will receive returns for the funds that have been invested. Or in other words, corporate governance is a trust given by investors to companies in providing benefits to them. Besides, investors believe that company managers will never embezzle or steal their invested funds. Keep in mind that the imbalance between the authorities of information will trigger the emergence of a condition called information asymmetry. If this happens between management and the owner, then it will provide an opportunity for managers to manage earnings to mislead shareholders regarding the company's economic performance.

Related to this theory, leverage is expected to reduce the occurrence of agency conflicts within the company. A high degree of leverage is meant to reveal more information because it is fundamental to supporting the effectiveness and efficiency of a company's operations. When the company is in debt, then at that time the company is also obliged to pay back the debt. Under these conditions, managers must increase the company's profitability to immediately make these returns. The existence of these debts will make management easier to run the company's operations.

\section{B. Stakeholder Theory.}

Stakeholder theory is a theory which states that the success or failure of a company will highly depend on the company's ability to balance the diverse interests of the stakeholders because the presence of stakeholders is very important for the company's sustainability. Stakeholders are internal and external parties such as the government, competing companies, the surrounding community, the international environment outside the company (NGOs and the like), environmental observers, company workers, minorities and others whose existence influences and is influenced by the company.

According to Joko (2016) [6], all stakeholders in this theory have the right to obtain information about company activities during a certain period that can influence decision
Table 4.

Global Reporting Initiative (GRI) Versi 4.0

\begin{tabular}{cc}
\hline \hline No & Aspect \\
\hline 1 & Economy Category \\
2 & Environmental Category \\
3 & The Sosial Category in Labor Practice and Work Comfort \\
4 & Human Rights Category \\
5 & Community Category \\
6 & Product Performance Responsibility Category \\
\hline \hline
\end{tabular}

making. Thus, the company is not only responsible for the stakeholders but also must be accountable to the environment and surrounding communities by carrying out CSR disclosures. According Freeman (1984) in Mayang (2018) [16] concluded that the real purpose of a company is to meet the needs of stakeholders, i.e. those affected by the decisions taken by the company. The survival of a company depends on the support of its stakeholders, and that support should be sought so that the company should seek that support. The stronger the stakeholders. The more the companies are trying to adapt. Stakeholder theory is important in this research because the theory is related to the parties that are interested in the company; those who will be affected and influenced by the activities of the company, such as accountability of management to stakeholders in the form of CSR activities and corporate financial performance.

\section{Trade-Off Theory.}

The trade-off theory proposed by Modigliani and Miller confirms that the existence of an optimal capital structure can provide the maximization of the value of the company to balance the costs and benefits of additional debt [13]. The purpose of this theory is to explain the fact that corporate financing comes in part from debt and part from equity. If the company experiences a profit, the profit will be financed by debt. For example, the existence of tax savings that reaches the maximum amount must be compared with the cost of the possibility of financial distress. So, in general, the trade-off theory states when this happens the leverage level in the company is optimal. Watkins in Zachary (2019) [17] argues that businesses that use debt have the potential to improve company operations and increase company ROA and ROE through tax savings. The use of this debt has an impact if the rate of return on investment or assets is greater than the rate of return on debt. The implication of this theory is that a company that has high profitability will try to reduce the tax burden to be paid by increasing its debt ratio.

\section{Return On Assets.}

ROA is one of the analyses of financial profitability ratios that uses general methods to measure company performance in the financial sector. This ratio compares one thing with another so that it can show the relationship or correlation of a financial statement in the form of a balance sheet or profit and loss [6]. According to Werner, Return On Assets (ROA) is one of the profitability ratios as a measure of the company's ability to use all assets that the company has to generate profits [18]. If the value of this ratio is getting higher, it means that the use of all assets in the company is very optimal.

ROA is used to measure the company's ability to generate net income based on assets owned. the greater the value of 
The $1^{\text {st }}$ International Conference on Business and Engineering Management (IConBEM)

February $1^{\text {st }} 2020$, Institut Teknologi Sepuluh Nopember, Surabaya, Indonesia

ROA, the more effective management will be in managing assets to generate profits [19]. Ahmad Azmy (2019) in his research explains the profit of a company is measured by the success of the company and the ability to use its assets productively, thus the probability is the ability of company can be known by comparing the profits earned in a period with the total assets or total capital of the company [14].

\section{E. Environmental Performance.}

In recent years, the relationship between environmental responsibility and a firm's financial performance or competitiveness has come under greater scrutiny by - and has become the subject of debate in - the academic community [20]. Not with standing the tremendous number of scientific publications on the link between environmental responsibility and firm performance. Most research in the current literature has focused on the direct relationship between environmental responsibility and firm results. In particular, these studies often analyse whether and to what extent a firm's environmental responsibility influences its financial results. In this context, three major theoretical approaches have been identified in the literature.

Joko (2016) explains that environmental performance is a company performance that focuses on company activities that are directly related to preserving the environment and reducing the environmental impact arising from company activities and this is considered as corporate ethics [6]. According to Joko (2016), environmental performance is a company performance that focuses on company activities that are directly related to preserving the environment and reducing the environmental impact arising from company activities and this is considered as corporate ethics [6].

The application of environmental performance in Indonesia is carried out by the Government. Law of the Republic of Indonesia (RI Law) No. 32 of 2009 describes the Protection and Management of the Environment article 43 paragraph (3) letter C. In carrying out its responsibilities to the environment, the government has initiated the Company Performance Rating Assessment Program, or better known as PROPER. The PROPER performance of each company is interpreted by the colors listed in the Table 3.

\section{F. CSR.}

CSR is considered as a form of company sincerity in setting aside some of the company's assets to reduce the possibility of negative impacts and to try to maximize the operational impact of the company on all parties interested in economic activities and social and environmental activities. Syahrul (2019) hold that CSR is an accounting concept that can make companies driven to carry out their responsibilities to the environment and society [9]. CSR arises a result of the company's operational activities which not only have a positive impact, but also have a negative impact, especially for the community and the environment around the company. However, there are still inconsistencies amongthe existing research results [16].

The implementation of CSR can improve the company's performance as its reputationand competitiveness increase. Research on the effect of CSR on a company's financialperformance has been conducted extensively. On June 8, 2017, the Global Reporting Initiative (GRI) launched the latest GRI Standards in Indonesia, namely GRI version
4.0 which consists of 91 items. The aspects of CSR disclosure are show in Table 4.

\section{G. Independent Board of Commissioners.}

Andri (2015) states that the board of commissioners is a representative of shareholders in a Limited Liability company whose function is to oversee the management of company data by management (Director) [15]. According to Sophie et al (2019), based on the regulation of The Minister of SOEs No. Per/MBU/01/2011, the board of the independent commissioner is a member of theboard of commissioners who have no financial ties, management, ownership and/or family relations withother members of the board of commissioners, the board of directors, and/or shareholders controllers that can affect their ability to act independently [21].

However according to Doddy et al (2019), board of commissioners (BoCs) is a company element that has duties to supervise and to give advice to board of directors [22]. The BoCsis an important element in corporation because they have the responsibility to make sure that board of directors is doing their work well and conducting good corporate governance. As the supervisory board, this board has to monitor the board of directors. Since they are formally separated from the board of directors, therefore it might be argued they can monitor more independently. Unlike in the one-tier board systems, thereshould beno conflict of interests between management and monitoring in two-tier board systems.

\section{H. Audit Committee.}

Andri (2015) explained that the role of audit committee was regulated in Bapepam No. Kep-29/M/2004 where a work unit is formed by the board of commissioners in order to help carry out their duties and functions [15]. Arif Effendi explained, the Audit committee played an important role in realizing GCG because it was the "eyes" and "ears" of the board of commissioners in order to oversee the running of the company [4].

Audit Committee acts as an independent management examiner and as a lawyer for users outside the financial statements in ensuring that financial statements are accurately presented that describe the company's economic activities. The audit committee has the task of assisting the board of commissioners by providing professional and independent opinions to improve the quality of work and reduse deviations in management of the company [14].

Riri Mayliza (2019) also explained the relevancy of audit committee and financial performance which can be seen from the function of supervision done by the audit committee [10]. the audit committee also has an independent duty to ensure whether the financial report that has been made and complied by the manager and the board of commissioners is clear and accountable or not.

\section{Debt Ratio.}

Makwe S. I. (2019) said the debt ratio used in corporate finance is used to measure the company's ability to handle its obligations by comparing the company's total debt with its total assets [13]. Debt ratio on the other hand is a financial leverage used in corporate finance to measure a company's 
The $1^{\text {st }}$ International Conference on Business and Engineering Management (IConBEM)

February $1^{\text {st }} 2020$, Institut Teknologi Sepuluh Nopember, Surabaya, Indonesia

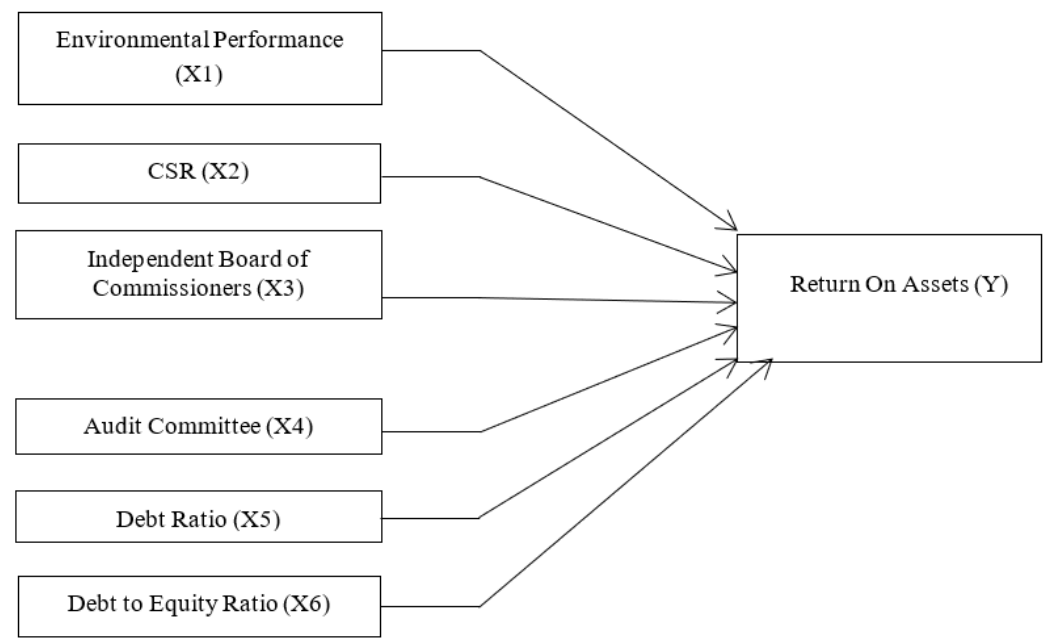

Figure 1. Conceptual Framework of Relationship among Thought Variables

ability to handle its obligations. It gives users a quick measure of the amount of debt that a firm has on its financial position compared to its assets. When the debt ratios are integrated with fixed assets growth ratios, it provides insights onthe structure of assets financing. That is, since the mean and median short-term debtratios are relatively higher than the fixed assets ratios, it is obvious that all fixed assetsgrowth is financed by short-term debt.

\section{J. Debt to Equity Ratio.}

Umer (2018) explains that this ratio is very important to measure financial leverage because it shows how many companies use debt to operate their financial activities and shows the relationship between debt and equity [11]. Debt to Equity Ratio is indicates what proportion of debt to equity the company is using to finance its assets. The extent to which a firm uses debt funding or financial leverage has implications for the firm. By raising funds through debt, shareholders are able to maintain control without having to increase investment [13]. Enekwe et al in Makwe S. I. (2019) submits that debt to equity ratio is a financial ratio indicating the relative proportion of equity and debt used to finance a company's assets which is an indicator of the financial leverage [13].

\section{RESEARCH METHOD}

This paper is conceptual and qualitative. It was published from some major publications. The article discusses environmental performance, CSR, independent boards of commissioners, audit committees, debt ratios, and debt to equity ratios to financial performance.

\section{SUMMARY}

Based on the explanation of the theory and previous research above, the framework used in this study is as shown in Figure 1.

\section{A. Effect of Environmental Performance on Financial Performance}

According to Hahologan in Rima Dewi (2019) explained that environmental performance is the company's mechanism to voluntarily implement the company's attention to the environment into activities and interactions with stakeholders, which exceeds the responsibility of the company in the legal field [3]. The management of environmental performance aims to meet the environmental balance in every company activity. The implementation of environmental performance indicators is expected to reduce the presence of waste or reduce pollution caused by company activities and be able to increase the level of profitability of the company.

Mario (2017) explains the traditional view suggests a "negative association" between environmental responsibility and corporate performance [20]. More specifically, this view posits that firms with positive environmental performance suffer competitive disadvantages associated with the higher costs of enhanced environmental performance. Those firms that comply with regulations (by increasing expenditures on environmental protection) face higher production costs and are less competitive in domestic and foreign markets as a result.

\section{B. Effect of CSR on Financial Performance}

Disclosure of social responsibility is done to maintain a harmonious relationship between the company and stakeholders. This is very closely related to corporate CSR disclosures that incorporate social elements in accounting. The higher the disclosure of CSR, the financial performance of the company will certainly increase. Besides, CSR is considered very important for economic activities because CSR pays attention to all kinds of aspects ranging from the company's economic activities and the relationship between the company and stakeholders.

This argument is supported by the results of previous studies conducted by Elif-Akben (2019), Rima Dewi (2019), Ni Luh Putu et al (2017) and Putri Asiza (2015) [2], [3], [7], [19].

\section{Effect of Independent Board of Commissioners on Financial Performance}

The board of commissioners does not have direct power or authority over the company because the board of commissioners has to supervise and provide input to the board of directors in the company. The effect of board size on the company's financial performance has different results and opinions. First, too many boards of commissioners will result 
The $1^{\text {st }}$ International Conference on Business and Engineering Management (IConBEM)

February $1^{\text {st }} 2020$, Institut Teknologi Sepuluh Nopember, Surabaya, Indonesia

in a deterioration in the company's performance because it will experience difficulties in communicating and coordinating among members of the board of commissioners.

This opinion is supported by previous research conducted by Ahmad Azmy, et al (2019) which states that the board of commissioners does not affect the company's financial performance [14]. Second, the board of commissioners has a positive and significant effect on financial performance. This indicates that the more members of the board of commissioners, the supervision conducted on the board of directors will be much better and will get some input or options that are much better as well. This is supported by the results of previous research conducted by Syahrul (2018) who measured the board of commissioners by using the number of boards of commissioners in the company [9].

\section{Effect of Audit Committee on Financial Performance}

The audit committee has now received positive responses from various parties, especially the government. This positive response was also felt by the community due to the purpose of forming an audit committee to maintain public confidence in the auditing, accounting, and control systems. With the existence of an audit committee, the company's Internal Control System (SPI) will be further improved if it cooperates with the internal audit. The existence of the audit committee in addition to bringing internal impact also brings external impact on the company, where companies that already have an audit committee tend to have higher share prices and are more attractive to investors. With more and more investors interested in the company, the company's financial performance will increase.

This argument is supported by previous research conducted by Riri Mayliza, et al (2019) and Ahmad Azmy, et al (2019) which proves that the audit committee influences the company's financial performance [10], [14]. In research conducted by Riri Mayliza, the audit committee was measured using the number of audit committees in the company.

\section{E. Effect of Debt Ratio on Financial Performance}

The debt ratio or debt ratio is the leverage ratio used in companies to evaluate the company's financial structure and financing operations. Usually, the more debt compared to the assets owned by the company, the greater the leverage and risk faced by the company are considered to be at a fairly high level of risk. The lower the level of the debt ratio, the better the company is because a small portion of the company's assets is financed by debt and vice versa.

There is an assumption that the company will get better when using greater debt. With an increasingly large debt value, the value of the company's assets will increase so that it can finance all activities or operations of the company with the aim of improving the company's financial performance. With the greater resources, it is also probable that the profits of the company will increase and are followed by an increase in risk as well [13].

\section{F. Effect of Debt to Equity Ratio on Financial Performance}

Short-term or long-term loans can reduce overall company performance According to Awais Mustabar and Iqbal Wateen in the journal Umer (2019) [11]. If the amount of money borrowed is less than the total amount of the company's equity will make the company have to work very hard. If the amount of debt borrowed is more than total company equity, the company's performance decreases and it becomes an important task for financial managers to evaluate the value of the company's overall equity before dealing with leverage.

This argument is supported by research conducted by Umer (2019) which explains that when companies have more growth opportunities, the company faces a more conservative leverage policy [11]. That is, high-interest rates and more complicated financial leverage policies have a negative impact on company performance.

\section{G. Limitations}

The lack of paper on Financial Performance makes the depth of discussion rather limited.

\section{H. Recommendation}

The results of this conceptual framework can be carried out with further empirical research related to financial performance as measured by ROA.

\section{REFERENCES}

[1]

S. Bahri and F. A. Cahyani, "Pengaruh kinerja lingkungan terhadap corporate financial performance dengan corporate social responsibility disclosure sebagai variabel I Ntervening (Studi empiris pada perusahaan manufaktur yang terdaftar di BEI),' Ekonika J. Ekon. Univ. Kadiri, vol. 1, no. 2, pp. 117-142, 2016, doi: 10.30737/ekonika.v1i2.11.

[2] N. L. P. Widhiastuti, I. D. . D. Suputra, and I. G. . N. Budiasih, "Pengaruh kinerja lingkungan pada kinerja keuangan dengan Corporate Social Responsibility sebagai variabel intervening," $E$ Jurnal Ekon. dan Bisnis Univ. Udayana, vol. 6, no. 2, pp. 819-846, 2017.

[3] R. D. Nawangsari and P. Ika Nugroho, "Pengaruh IndikaPengaruh indikator kinerja ekonomi, indikator kinerja lingkungan dan indikator kinerja sosial terhadap profitabilitas perusahan manufakturtor Kinerja Ekonomi, Indikator Kinerja Lingkungan dan Indikator Kinerja Sosial terhadap Profitabilitas," Int. J. Soc. Sci. Bus., vol. 3, no. 2, p. 162, 2019, doi: 10.23887/ijssb.v3i2.17644.

[4] M. A. Effendi, The Power of Good Corporate Governance: Teori dan Implementasi. Jakarta, Indonesia: Salemba Empat, 2016.

[5] A. Lako, Dekonstruksi CSR \& Reformasi Pradigma Bisnis \& Akuntansi. Jakarta, Indonesia: Erlangga, 2011.

[6] J. Setyono, "Pengaruh kebijakan sosial dan kinerja lingkungan terhadap kinerja keuangan perusahaan manufaktur go public di Bursa Efek Indonesia,” J. Bus. Bank., vol. 5, no. 2, p. 183, 2016, doi: 10.14414/jbb.v5i2.702.

[7] E. Akben-Selcuk, "Corporate Social Responsibility and financial performance:The moderating role of ownership concentration in Turkey," Sustainability, vol. 11, no. 13, 2019, doi: 10.3390/su11133643.

[8] A. Sutedi, Good Corporate Governance. Jakarta, Indonesia: Sinar Grafika, 2012.

[9] S. Effendi, "The effect of disclosure of Corporate Social Responsibility and good corporate governance to ROA in Sri Kehati Index," in Proceedings of the 5th Annual International Conference on Management Research (AICMaR 2018), 2018, pp. 79-82, doi: 10.2991/aicmar-18.2019.18.

[10] R. Mayliza, A. S. Dewi, and L. F. Sari, "The influence of good corporate governance towards financial performance using earnings management as the intervening variable at banking companies listed in Indonesia's stock exchange," in The First Economics, Law, Education and Humanities International Conference (The First ELEHIC), 2019, vol. 3, no. 14, pp. 472-490, doi: $10.18502 / \mathrm{kss} . v 3 \mathrm{i} 14.4332$.

[11] U. Iqbal and M. Usman, "Impact of financial leverage on firm performance," SEISENSE J. Manag., vol. 1, no. 2, pp. 70-78, 2018, doi: 10.33215/sjom.v1i2.13.

[12] I. Dalci, "Impact of financial leverage on profitability of listed manufacturing firms in China," Pacific Account. Rev., vol. 30, no. 4, pp. 410-432, 2018, doi: 10.1108/PAR-01-2018-0008.

[13] M. S. Ivo and M. Anyanwaokoro, "Relating financial leverage to 
The $1^{\text {st }}$ International Conference on Business and Engineering Management (IConBEM)

February $1^{\text {st }} 2020$, Institut Teknologi Sepuluh Nopember, Surabaya, Indonesia

corporate performance: A case of cement manufacturing firms in Nigeria," South Asian J. Soc. Stud. Econ., vol. 3, no. 4, pp. 1-14, 2019, doi: 10.9734/sajsse/2019/v3i430114.

[14] A. Azmy, D. R. Anggreini, and M. Hamim, "Effect of Good Corporate Governance on company profitability RE \& property sector in Indonesia," J. Akunt., vol. 23, no. 1, pp. 18-33, 2019, doi: 10.24912/ja.v23i1.457.

[15] A. Veno, "Pengaruh Good Corporate Governance terhadap kinerja perusahaan pada perusahaan manufaktur go publik," BENEFIT $J$ Manaj. dan Bisnis, vol. 19, no. 1, pp. 95-112, 2015, doi: 10.23917/benefit.v1i1.1406.

[16] M. Mahrani and N. Soewarno, "The effect of good corporate governance mechanism and corporate social responsibility on financial performance with earnings management as mediating variable," Asian J. Account. Res., vol. 3, no. 1, pp. 41-60, 2018, doi: 10.1108/ajar-06-2018-0008.

[17] Z. M. Gathara, J. M. Kilika, and J. N. Maingi, "Effect of leverage on financial performance of selected companies listed in Nairobi Securities Exchange, Kenya," Int. J. Innov. Financ. Econ. Res. vol. 7, no. 1, pp. 10-33, 2019.
[18] W. R. Murhadi, Analisis Laporan Keuangan, Proyeksi dan Valuasi Saham. Jakarta, Indonesia: Salemba Empat, 2013.

[19] P. A. A. A. Rahmah and R. Iramani, "Pengaruh corporate social responsibility pada kinerja keuangan perusahaan pertambangan,' J. Bus. Bank., vol. 5, no. 2, p. 195, 2015, doi: 10.14414/jbb.v5i2.703.

[20] M. Testa and A. D'Amato, "Corporate environmental responsibility and financial performance: Does bidirectional causality work? Empirical evidence from the manufacturing industry," Soc. Responsib. J., vol. 13, no. 2, pp. 221-234, 2017, doi: 10.1108/SRJ-02-2016-0031.

[21] S. T. Adriaty, B. Purwanto, and W. J. Ermawati, “A determinan of state-owned enterprises profitability with an independent board of commissioners as moderation variables," J. Keuang. dan Perbank., vol. 23, no. 1, pp. 109-122, 2019, doi: 10.26905/jkdp.v23i1.2519.

[22] D. Setiawan, F. M. Taib, L.-K. Phua, and H.-K. Chee, "IFRS and earnings management in Indonesia:The effect of independent commissioners," Int. J. Bus. Soc., vol. 20, no. 1, pp. 37-58, 2019. 